\title{
Compositional and Verbal Aspect in Greek: The Aorist Imperfect Distinction and the Article-Aspect Interplay
}

\author{
By Desislava Dimitrova ${ }^{*}$ \& Krasimir Kabakčiev ${ }^{ \pm}$
}

\begin{abstract}
According to an aspectological model proposed by Kabakčiev in 1984, later developed and sophisticated, languages differ according to whether they mark aspect (perfectivity and imperfectivity) on verbs, as in the Slavic languages among others, or through nouns/NPs featuring (non-)boundedness which is transferred onto verbs, as in the Germanic languages - among others. In this model of compositional aspect (CA), Bulgarian is a borderline case with a perfective-imperfective and an aorist-imperfect distinction and a definite article only (no indefinite), and the model is used to analyze Greek, a language exhibiting identical features. NP referents play a major role for the compositional explication of aspect. The study finds that Greek is of the same borderline/hybrid type of language as Bulgarian, featuring verbal aspect (VA) predominantly, but also peripherally $C A$. The aorist/imperfect distinction exists both in Greek and Bulgarian to offset the structural impact of the definite article. Analyzed are some conditions for the explication of CA in Greek and they are found similar to those in Bulgarian. However, there are specificites and differences between the two languages that must be further studied and identified.
\end{abstract}

Keywords: verbal aspect, compositional aspect, definite article, article-aspect interplay, aorist-imperfect contrast

\section{General Theoretical Background - An Overview of Compositional Aspect}

This study takes as an approach to the language data that it aims to analyze, mainly from Modern Greek, the theory of CA, as represented in certain publications - some recent (Bulatović 2013, 2019, 2020, Kabakčiev 2019), others long-established (Vendler 1957, Verkuyl 1972, 1993, Kabakčiev 1984, 2000). CA has been known in linguistics as a fundamental and supposedly universal phenomenon for half a century since Verkuyl (1972), but in spite of its widely recognized significance it has also generated serious theoretical controversies (Kabakčiev 2019). Among the goals of this paper is the description of certain features of Greek related to the interdependence between the definite article and aspect in general, on the one hand, and the aspecto-temporal aorist-imperfect distinction, on the other, the interdependence proposed a long time ago for Bulgarian but generally ignored in the literature. Initially pursuing the articleimperfect interdependence, we came upon features of Greek related either to the

\footnotetext{
*Assistant Professor, Medical University of Plovdiv/Paisii Hilendarski University of Plovdiv, Bulgaria.

${ }^{ \pm}$Independent Researcher, Bulgaria.
} 
explication of Vendlerian situational values or to their forcing from other aspectual values, which additionally engaged our attention. Concealed in the aorist-imperfect distinction in Greek, we found the interesting and systematic phenomenon of aspect coercion - outlined in the paper and considered as subject to further research.

In an intricate model of aspect, launched 37 years ago and later developed (Kabakčiev 1984, 2000), the major function across languages of grammatical aspect, including the aorist-imperfect distinction, is the quantification in temporal terms of participants in situations. ${ }^{1}$ Kabakčiev's idea of an all-embracing articleaspect interplay is primarily based on Verkuyl's (1972) model of CA, and Verkuyl's model was inspired by Vendler's classification of situations: types of occurrences whose effectuation is made possible by verbs and accompanying elements such as objects and adverbials. The difference between Vendler's (1957) model and Verkuyl's is that while Vendler's is restricted to what separate verbs and verbs with their accompanying elements (objects, adverbials) can do for explicating aspect, in Verkuyl's (1972) the phenomenon of CA is entirely, with no exception at all, grounded in the whole sentence.

Kabakčiev's version of the CA theory that we will employ is based on Verkuyl's (1972) model but departs in some key respects from Verkuyl's (1993) later atemporal version and encompasses four major theses: (i) the temporality of situation participants (Kabakčiev 2000; 2019, pp. $207-210$ ); ${ }^{2}$ (ii) the mechanism of mapping temporal values in the sentence from nominal referents onto the verb referent - as is generally the case in the Germanic languages, and vice versa, from the verb referent onto the nominal referents - as in the Slavic languages (Kabakčiev 2000, pp. $123-151$ ); (iii) the recognition of two different types of aspect structurally and in cross-language terms (but not semantically) - compositional and verbal. CA is typical of the Germanic languages and located in the sentence; VA is found in the verb and typical of the Slavic languages (Kabakčiev 2019, pp. $212-214) .{ }^{3}$ But VA is also represented in English, by the progressive (discussed below). VA is either a "ready lexical item", perfective or imperfective, as in Greek and the Slavic languages, or is syntactically realized with the relevant value, as in the English progressive and the aorist/imperfect as in Greek or Bulgarian; (iv) the article (definite and indefinite) in the present model and within the perfective Verkuylian schema (Verkuyl 1972, 1993) is a covert marker of boundedness - on those nominal components that are situation participants, while the zero article is a marker of non-boundedness. The article (althe) is a quantifier in Verkuyl's (1972, 1993) CA model, whether the definite one is used with singular or plural nouns. The zero article, regardless of whether it is with count or mass nouns, is treated as

\footnotetext{
${ }^{1}$ Participants in situations, also called verb arguments (Verkuyl 1972, 1993), was introduced as a term in Kabakčiev (1984: 670), for being better suited to aspectological research (Kabakčiev 2019, p. 201). Not every NP in a simple sentence is a situation participant/verb argument.

${ }^{2}$ Verkuyl's (1993) aspectual model is atemporal in that it ascribes temporality to referents of verbs only, not to noun/NP referents.

${ }^{3}$ The crucial difference between VA-CA is in the effectuation of perfectivity. Languages that prototypically feature VA (Slavic, Greek) have perfective verbs as lexical entries. Languages that prototypically feature CA (Germanic, Romance, Finnish) lack perfective verbs and depend on CA for the effectuation of perfectivity.
} 
an entity de-quantifying the relevant NP. ${ }^{4}$ In Kabakčiev's model, the article is likewise treated as a quantifier and the zero article as an entity de-quantifying the $\mathrm{NP}$, but with the difference that the article is also understood as a covert marker of temporal boundedness of NP referents, and the zero article as a marker of temporal non-boundedness of NP referents (Kabakčiev 1984, 2000, 2019).

\section{Compositional Explication of Aspect and the Progressive as an Instantiation of VA}

The compositional explication of perfectivity in English (and other languages) - in both Verkuyl's and Kabakčiev's models, takes place at the level of the sentence, through Verkuyl's perfective schema, as in (1a) below. The subject and the object are quantified by an article (definite or indefinite) and their referents are bounded. ${ }^{5}$ In Kabakčiev's $(1984 ; 2000)$ model they constitute temporally bounded entities, not atemporal as in Verkuyl (1993); the lexical nature of the verb (telic) in (1a) allows the explication of perfectivity. Conversely, imperfectivity in (1b) is not explicated compositionally but is directly expressed by the progressive - an instantiation not of CA but of VA: ${ }^{6}$
a. The boy threw a stone
b. The boy was throwing a stone - when I saw him from the fast moving train

A major tenet in Verkuyl's (1993) aspectual model is that perfectivity is realized in sentences such as (1a) because there is no leak in any aspect-related component: no leak in the verb and in the NPs that are situation participants. A leak can be represented by a non-quantified NP $(2 \mathrm{a}, \mathrm{c})$ or by a verb with an atelic lexical meaning disallowing perfectivity, (2b). Sentences (2a, b, c) vs (1a) demonstrate how Verkuylian leaks trigger imperfectivity: ${ }^{7}$

$$
\text { a. The boy threw stones } \text { LEAK }
$$

\footnotetext{
4"Zero article" is standardly taken to mean that the relevant NP contains no other quantifier. In English many nominal modifiers are quantifiers (some, any, all, many, my, this/these), markers of what Verkuyl (1972) calls specified quantity. However, the only marker of non-specified quantity and hence non-boundedness is the zero article. An NP with an article is, hence, quantified and its referent bounded; a bare NP is de-quantified and its referent non-bounded. But (non-)boundedness depends on other factors too.

${ }^{5}$ An NP referent can be bounded without a superficial marker: John and he are bounded with a covert article; John means "the person named John", he means "the person referred to as "he". ${ }^{6}$ Grammatical imperfectivity, again verbal (not compositional), is also systematically present in English, realized by the progressive and by the would +inf and used to+inf constructions which should be called imperfectivity markers (in its habituality variant), not "habituality markers" as is done in English grammars. The presence of verbal imperfectivity in English does not make it a VA language - because English does not feature perfective verbs, in contrast to the Slavic languages, Greek, Old English, etc.

${ }^{7}$ The leaks are called Verkuylian in honor of their finder (Kabakčiev 2019, p. 204).
} 
b. The boy carried ${ }_{\text {LEAK }}$ a stone

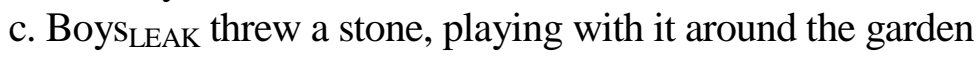

Sentences such as (1a) demonstrate Verkuyl's (1993, pp. 328 -349) perfective schema, $(2 \mathrm{a}, \mathrm{b}, \mathrm{c})$ - the imperfective one. In the latter, at least one leak is obligatorily present. ${ }^{8}$

Given that sentences such as (1a) are perfective - not always but as a default (Kabakčiev 2019, pp. 205 -207), sentences such as (1b), imperfectivized by the progressive, contain such situation participants that could not in any way be temporally bounded as in (1a), despite the subject and the object still being accompanied by an article. The elimination of the temporal boundedness of subject- and object-NP referents in sentences like (1b) and in similar ones containing progressives is effectuated through the mapping mechanism, as part of the model in which CA is "an all-pervading and perpetual process of mapping temporal features between elements of the sentence, especially between referents of verbs and of nominals that are participants in situations" (Kabakčiev 2019, p. 212). This generalization corresponds to data from languages that are well-studied - Germanic and Slavic, ${ }^{9}$ and has stood the test of time.

Also non-bounded temporally are subject and object referents in sentences such as $(2 \mathrm{a}, \mathrm{c})$ because of the de-quantification of subject or object, triggering a leak. Important questions arise here. If the object in sentences such as (2a) is nonquantified, hence non-bounded - spatially as in Verkuyl's model or temporally as in Kabakčiev's, must the referent of the subject, remaining quantified by an article, be treated as bounded? Analogously, in sentences such as (2c), where the subject is non-quantified, hence non-bounded, must the referent of the object, remaining quantified by an article, be treated as bounded - or as non-bounded? Verkuyl does not propose answers to such questions. His concern is the aspectual interpretation a sentence receives because of the presence/absence of a leak. Kabakčiev's (2000, 2019) position is different because of his temporal model, in which all situation participants are temporal entities. When a non-quantified subject makes a perfective sentence imperfective, as in (1a) $>(2 c)$, the referent of the object also undergoes a change, becoming temporally non-bounded, despite remaining superficially quantified. Analogously, when a non-quantified object makes a perfective sentence imperfective, (1a)>(2a), the referent of the subject becomes temporally nonbounded, despite remaining superficially quantified (Kabakčiev 2019). ${ }^{10}$

\footnotetext{
${ }^{8}$ The perfective schema also demonstrates Verkuyl's (1993, pp. 5 -32) so-called plus-principle. All sentence components must have plus-values (quantified situation-participant NPs, telic verbs). ${ }^{9}$ Finnish, a language structurally completely different from most European languages, entirely falls within the described paradigm, belonging to CA languages, with "nominal aspect" (Kabakčiev 2019 , p. 218). Finnish features no VA and no articles but its markers of boundedness are also located on nouns. The encoding of boundedness is executed by the nominative/accusative case. While non-boundedness in languages like English is encoded using the zero article, in Finnish and similar languages this job is done by the partitive case.

${ }^{10}$ This solution is impossible to achieve in a model with atemporal situation participants. Cf. Krifka's (1992, p. 44) observation that there may be a correspondence between a book and its reading to the end, but there is no correspondence between parts of the person reading and the
} 


\section{An Overview and Critique of the Literature on Greek Aspect vs Germanic/ Slavic Aspect}

Greek and Bulgarian belong to different groups (Hellenic and Slavic) of the Indo-European ancestry. But, located in the Balkansprachbund, they share many common features: phonological, lexical, grammatical, etc., due to the centuries of physical proximity of the two nations and the unavoidable mutual influence. Unfortunately, although considerable research has been done on the Balkansprachbund and on Greek and Bulgarian separately, many of their characteristics remain understudied. VA, the aorist-imperfect distinction and the definite article are among them, in the sense that these features are, of course, well-known but their interdependence remains unconfirmed. With this study we aim to correct the deficiency. ${ }^{11}$ We did our best to check the literature on Greek aspect - mainly in English, and we found the following.

Greek has VA just like the Slavic languages, and Slavic aspectology has a huge tradition but publications on Greek aspect in Slavicist terms are rare (Tarpomanova 2013, Marku 2019, Dimitrova 2019a, 2019b, 2019c); some offer mixed approaches, Germanic-Slavic (Bielecki and Trąba 2018, Trąba 2019). Most publications do not take a clear stand on whether Greek, being unquestionably a VA language, should be analyzed through a VA approach (Slavic-like) or this could be done successfully in CA terms too. Also, unfortunately, despite the widely acknowledged thesis that CA is not VP-based but sentence-based (Verkuyl 1972, 1993, Dowty 1979, p. 64, Kabakčiev 2000, Bulatović 2019, 2020), the idea that CA lies within the VP continues, surprisingly, to hold sway in many studies. Common assertions are that aspect represents "conceptual properties of situation types denoted by whole VPs" (Horrocks and Stavrou 2007, p. 637) and that it is expressed "by the predicate" (Andreou and Tsimpli 2017, p. 307). Extreme views are even upheld: "-ed designates perfectivity" (Dosi 2017, p. 215) - which means that English CA is not even VP-based but verb-based. Dosi et al. (2017, p. 77) argue that sentences with non-quantified objects such as Mary ate apples denote perfectivity. This is in contradiction to Vendler's aspect - which the authors call lexical (Dosi et al. 2017, p. 79). Vendler's model rests on the idea that eat an apple/the apple are perfective phrases, and ate apples an imperfective one. How ate apples can be perfective and why Vendler's aspect is called lexical remains unclear. ${ }^{12}$ Some authors blend VA and CA into one: "aspectual composition occurs when grammatical aspect [...] and eventuality types [...] carried by the

reading event. In a temporal model with situation participants as temporal entities (Kabakčiev 2019, pp. 214-215) such a problem simply does not exist.

${ }^{11}$ The problem of the historical development of the definite article in Bulgarian and Greek will not be handled here because of the insufficiency of research and historical evidence. For example, the emergence of the Bulgarian article is hypothesized to have taken place somewhere between the $10^{\text {th }}$ and the $17^{\text {th }}$ century.

${ }^{12}$ Vendler's aspect could be called lexical when separate verbs are discussed: arrive (an accomplishment), hate (a state). When differences between eat an apple (accomplishment) and eat apples (state/activity) are at issue, for Vendler's aspect to be called lexical is tantamount to claiming that what changes the accomplishment ate an apple into a state/activity in ate apples is the lexical meaning of apples. 
verb along with its arguments combine" (Flouraki 2006). ${ }^{13}$ Georgakopoulos et al. (2019) rightly assume that Greek is a VA language while English and German are not, yet the latter are capable of explicating perfectivity - but no explanation is offered on how this is achieved. Sioupi (2005) claims a Germanic-Slavic approach to Greek aspect, naming Russian as a point of contrast. But no Slavic analysis is undertaken, not a single Slavic example is given. The approach is, therefore, purely Germanic, not a problem in itself. But, unfortunately, the sentence-level nature of CA is bypassed.

As for the view that the English preterit is perfective (Dosi 2017), considered obsolete today, it can, indeed, still be found - in isolated papers and in English grammars. The reason is that English grammars have been lagging behind modern aspectological research for decades. Bulatović (2020) has just poured some harsh yet fully justified criticism on almost all English grammars for their total failure to describe the article-aspect interplay and CA in general. English grammars have, indeed, been changing lately, but very slowly. A decade or two ago some grammarians started to admit that perfectivity is found systematically in English (Huddleston and Pullum 2002, pp. 118-125; Declerck et al. 2006, pp. 28-34). Others included Vendler's classes in their descriptions (Downing and Locke 2006) or mentioned in passing the existence of perfectivity (Fenn 2010, pp. 279-280). ${ }^{14}$ But the necessary radical restructuring of the aspecto-temporal sphere in English grammars is obviously a long way ahead.

We feel confident to make the generalization that publications on Greek claiming to use CA as an analytical tool systematically sidestep the role played by all referents of situation-participant NPs in a sentence. A certain exception is Trąba (2019, p. 42), who mentions the contribution of subject NPs for aspectual composition but restricts himself to "quantitative properties", bypassing the issue of how exactly arguments explicate aspect. Another publication discussing the impact of both subject and object in aspectual construal is Tsimpli and Papadopoulou (2006, p. 1596) - but it, too, does not explain how their features interact to produce an aspectual value. Kaltsa (2012, p. xiv) declares aspect to be sentence-based, but the contribution of subject NPs to aspect is ignored in this dissertation - aiming to describe Greek VA through a mixed approach, verbalcompositional. In our view, endeavors blending VA and CA are doomed to fail when no principled distinction is made between these two types of aspect. ${ }^{15}$

This overview of research on Greek aspect shows that its general line is incompatible with our approach, mainly because: (i) VA and CA are two distinct phenomena - structurally and in cross-language terms; (ii) CA is a sentence-level phenomenon, with no exception at all; (iii) situation participants are temporal entities playing a crucial role in CA.

\footnotetext{
${ }^{13}$ Although CA and VA are mirror images of each other (Kabakčiev 2000, pp. 158-161), structurally they are different phenomena that must be kept apart for a true understanding of the universal nature of aspect (Kabakčiev 2019, pp. 212-214).

${ }^{14}$ According to three reviews (Bulatovic 2018, 2020, Dimitrova 2019d), the only English grammar providing an exhaustive description of CA is Kabakčiev (2017).

${ }^{15}$ Blending VA and CA is a mistake made by Borer (2005) and Borik (2006), see Kabakčiev (2019, pp. 212-214).
} 


\section{CA, Biaspectuality and Disambiguation: Initially on Bulgarian Data}

Biaspectuality is a well-known Slavic phenomenon, also present in Greek. It amounts to a verb lexically encoding neither perfectivity, nor imperfectivity but realized as perfective or imperfective. The standard explanation is that aspect is "realized in context" but it is a vacuous one. If something in a context changes the aspectual interpretation of a verb, that something must be identifiable. We find it appropriate to start with sentences manifesting a similar Bulgarian phenomenon, verbs used with the opposite aspectual meaning:
a. Shte piya $\mathrm{IMPFV}_{\mathrm{M}}$ edno kafe i shte trygnapFv
'I will drink a coffee and leave'
b. Kak se pribira Ivan vkashti piyan? - Padne $e_{\mathrm{PFV}}$, stane $\mathrm{PFV}_{\mathrm{PF}}$
'How does Ivan go home drunk?' 'Falls, rises'

The first verb in (3a) is imperfective and this ought to be an instance of VA. But it is not, as the verb is used with a perfective meaning. The object-NP edno $k a f e$ 'a coffee' is quantified/bounded, the covert subject $I$ is also bounded, the verb piya 'drink' is telic, and the two NP-referents map their boundedness simultaneously onto the verb referent, despite the verb's imperfectivity. Therefore, on the one hand, this is a case of CA effectuation, within Verkuyl's perfective schema, but, on the other, it could also be interpreted as aspect coercion (see below). In (3b), conversely, padne 'falls' and stane 'rises' are perfective verbs but they signal imperfectivity. ${ }^{16}$ Greek will also be shown below to manifest this phenomenon of coercing (imposing/forcing) different or opposite aspectual/ situational values onto verbs.

How Bulgarian biaspectuality is disambiguated in CA terms was revealed in Kabakčiev (1984). Compare the perfective (4a) and the imperfective (4b, c, d), these sentences demonstrating an interplay between biaspectuality and the article (Kabakčiev 1984, p. 649):
a. Mehanitsite remontirahaBIASPAOR/IMP kolata
'The mechanics repaired the car'
b. Mehanitsite remontiraha BIASPAOR/IMP koli LEAK $_{\text {B }}$
'The mechanics repaired cars'
c. Mehanitsi LEAK $_{\text {remontiraha }}$ BIASPAOR/IMP kolata
'Mechanics repaired the car'
d. Mehanitsi $i_{\text {LEAK }}$ remontirahaBIASPAOR/IMP koli $_{\text {LEAK }}$
'Mechanics repaired cars'

Sentence (4a) is perfective - as a default, like its English equivalent. The definite article in the two NPs triggers temporal boundedness, transferred from both onto the verb. This is possible because the verb is ambivalent between perfectivity-imperfectivity, being simultaneously biaspectual and unmarked for

\footnotetext{
${ }^{16}$ The reasons are not discussed, for lack of space.
} 
aorist/imperfect. In a non-default reading (4a) could explicate imperfectivity in some contexts (Mehanitsite remontiraha kolata, sobstvenikat speshe 'The mechanics were repairing the car, the owner was sleeping'). Also, sentence (4c) appears imperfective in CA terms with the de-quantified subject but in real-world terms it is ambiguous between perfectivity/imperfectivity - and can be perfective if by mehanitsi 'mechanics' "some mechanics" is meant, as in English. The ambiguity of (4c), i.e., the breaking of CA rules, is due to the "knowledge of the world" factor. ${ }^{17}$ In principle, a Verkuylian leak triggers imperfectivity, see (4b, c); in (4d) the leaks are two. CA effectuation of perfectivity and imperfectivity with biaspectual verbs ought to be possible in Greek too. But it is not possible in the past, where biaspectual verbs receive aspectual marking (see below).

Among the opportunities in Bulgarian for CA explication is the use of imam 'have' as a light verb, often considered imperfective. However, imam explicates perfectivity when combined with nominals signifying boundedness: imam uspeh/ uslozhnenie/neblagorazumieto 'have success/a complication/the imprudence'. ${ }^{18}$ The nominal transfers its lexical boundedness onto the verb - which shows that imam is biaspectual. In Greek, aspect can also be explicated in this way, in CA terms, using écho 'I have' - even in the preterit, eícha 'I had'. As Holton et al. (1997, p. 132) put it, écho 'I have' has no perfective forms. Hence, if found to explicate perfectivity, it is biaspectual. Consider the phenomenon in Bulgarian, Greek and English - (5) are translation equivalents, those in (6) too:

a. Sled dvuboya mezhdu dvamata grosmaystori trima mladi shahmatisti imaha $a_{B I A S P}$ vazmozhnostta da pogovoryat $t_{\mathrm{PFV}} \mathrm{s}$ tyah (Bulgarian)

b. Metá to paichnídi metaxý ton dýo nkranmaítr, treis néoi paíktes skakioú eíchan $_{\text {BIASP }}$ tin efkairía na milísoun ${ }_{P F V}$ mazí tous (Greek)

c. After the game between the two grandmasters, three young chess players had the opportunity to talk to them

(6) a. Sled vseki dvuboy mezhdu dvamata grosmaystori mladi shahmatisti imaha BIASP vazmozhnostta da razgovaryat $_{\mathrm{IMPFV}} \mathrm{s}$ tyah (Bulgarian)

b. Metá apó káthe paichnídi metaxý ton dýo nkranmaítr, treis néoi paíktes skakioú eíchan ${ }_{\text {BIASP }}$ tin efkairía na milísoun ${ }_{\mathrm{PFV}}$ mazí tous (Greek)

c. After each game between the two grandmasters, young chess players had the opportunity to talk to them

This case is interesting because opportunity is ambivalent. It can signal both boundedness and non-boundedness, and so can the phrase had the opportunity. Although have in Bulgarian and Greek is usually considered an imperfective verb (in English a stative verb), the sentences in (5) differ from those in (6). The aspectual value of the have-phrase is perfective in the three languages in (5); in (6) it is imperfective. Why? In (5) it is perfective because: (i) the adverbial after the game indicates that what follows is a single completed event; (ii) the have-phrase

\footnotetext{
${ }^{17}$ Pragmatic factors often impact aspectual construal (Kabakčiev 2000, pp. 323 -324).

${ }^{18} \mathrm{~A}$ light verb is one with a reduced semantic content, such as do or make in do/make a jump or have in have a fall, where it is actually the noun, not the verb, that denotes the event/situation.
} 
allows the explication of perfectivity despite the alleged imperfective/stative nature of have; (iii) the NP three young chess players is quantified, hence temporally bounded, capable of mapping its boundedness onto the verb. Conversely, (6) are imperfective sentences, because: (i) the adverbial after every game indicates that what follows is a non-bounded iterative situation; (ii) had the opportunity allows the explication of imperfectivity; (iii) young chess players is a non-quantified/bare $\mathrm{NP}$, hence temporally non-bounded, indicating re-occurrence of chess players, hence non-boundedness is mapped onto the have-phrase.

Interestingly, in Greek (5b) the verb milísoun 'talk' is marked by the perfective

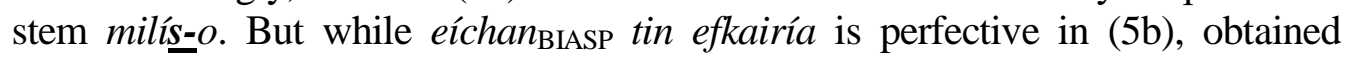
compositionally in Verkuyl's perfective schema, and the grammatically perfective milísoun 'talk' corresponds to this compositionally obtained perfectivity, conversely, milísoun 'talk' in (6b) signals imperfectivity (non-bounded iterativity) despite being grammatically perfective. Thus (6b) illustrates how in Greek a grammatically marked aspectual value can be coerced into the opposite one by a compositionally derived aspectual value. Such Greek cases of aspect coercion, even more systematic, will be discussed below, but the generalization that follows from (5)-(6) is that Greek and Bulgarian feature similarities even in specific domains such as biaspectuality disambiguation.

\section{CA in Greek: Biaspectuality, Disambiguation}

Just like all the Slavic languages, Greek features VA. The aspectual contrast is signalled by the presence/absence of an $-s$ - morpheme (sigmatic/asigmatic), the imperfective stem being the default one (Xydopoulos 1996, p. 127), and in the huge majority of cases aspect is directly expressed by the verb (Holton et al. 1997, p. 130ff, Kitis and Tsangalidis 2005, pp. $144-145$, Tarpomanova 2013, Babiniotis and Chleris 2015, p. 190, Dimitrova 2019a, 2019b, p. 185). However, as Xydopoulos (1996, p. 127) argues, the pattern is not fully systematic and the opposition "is often obtained by idiosyncratic morphophonemic changes with or without the $-s$ morpheme", and aspect is contextually distinguished. For example, "due to the nasal assimilation of the perfective suffix $-s$ there is no way to distinguish krine $\iota_{\mathrm{PFV}}$ 'he will judge' from krine l $_{\mathrm{IMPFV}}$ 'he is judging/judges"” (Aubrey 2014, p. 201). But if aspectual values in Greek are sometimes distinguished contextually, this means that aspectual disambiguation is realized compositionally, just like in English (and partly Bulgarian).

Let us again begin with a phenomenon resembling biaspectuality - an aspectually marked verb used with an opposite value. Such cases are discussed by Kitis and Tsangalidis (2005, pp. 146-153). Perfective events can be described using verbs marked for imperfectivity as in their example (7a), similar to Bulgarian (7b):

(7) a. Ótan ton skótosapFv péthena

'When I killed him I died with him'

b. Ubivam ${ }_{\mathrm{IMPFV}}$ go, i njama da mi migne $\mathrm{PFV}$ okoto 
'(lit.) I kill him and my eye won't blink'

However, in (7a), as noted by the authors themselves, the phenomenon is a stylistic effect rather than aspect coercion; also in (7b). Therefore, let us now consider some entities that can truly impact CA explication: nominals. A detailed description of English nominals denoting abstract entities and their effect on CA effectuation is made in Kabakčiev (2000, pp. 211-239). We can safely maintain here that the lexical nature of nominals standing for temporal entities is not only near-identical in Bulgarian and Greek, it is similar to the one observed in English. Compare the tables below with nominals outside sentences in the three languages. In Table 1 they denote bounded situations (accomplishments/achievements). Such nominals are typically accompanied by the indefinite article in English - which explicates specified quantity in Verkuyl's (1972) model and temporal boundedness in Kabakčiev's (1984, 2000, 2019). In Greek and Bulgarian, an indefinite numeral (Greek éna párti 'one party', Bulgarian edna sreshta 'one meeting') is sometimes needed to strengthen the lexical temporal boundedness (the issue is skipped here for lack of space).

Table 1. Nominals as Lexical Entries Signifying Bounded Situations (Accomplishments/Achievements)

\begin{tabular}{|l|c|c|}
\hline English & Bulgarian & Greek \\
\hline a fall & padane 'a fall' & ptósi 'a fall' \\
\hline a surgery/an operation & operatsiya 'a surgery' & epémvasi 'a surgery' \\
\hline a talk/a conversation & razgovor 'a talk' & syzítisi 'a talk' \\
\hline a meeting & sreshta 'a meeting' & synántisi 'a meeting' \\
\hline a party & parti 'a party' & párti 'a party' \\
\hline
\end{tabular}

The nominals in Table 2, conversely, signify non-boundedness (states/ activities) as lexical entries. In English they are typically used without an indefinite article.

Table 2. Nominals as Lexical Entries Signifying Non-Bounded Situations (States/ Activities)

\begin{tabular}{|l|c|c|}
\hline English & Bulgarian & Greek \\
\hline imagination & vaobrazhenie 'imagination' & fantasía 'imagination' \\
\hline understanding & razbirane 'understanding' & katanóisi 'understanding' \\
\hline pressure & natisk 'pressure' & piesi 'pressure' \\
\hline belief & vyara 'belief' & písti 'belief' \\
\hline love/hate & lyubov/omraza 'love/hate' & agápi/mísos 'love/hate' \\
\hline
\end{tabular}

The tables demonstrate how remarkably similar English, Bulgarian and Greek are in this area. Examples with biaspectual (aspectually ambivalent) have/had + a temporally bounded/non-bounded nominal nicely manifest the mechanism of mapping situational values from a nominal onto a verb in all the three languages. In (8), sentences from the Internet, the relevant nominals in Greek and in the English translations map their temporal boundedness onto the verb échei/have, 
whereby the échei/have forms acquire perfectivity (but see below about a possible opposite subject-NP impact). Note the absence in Greek of an indefinite numeral in the échei+N phrases in (8), e.g., échei ptósi 'have fall', unlike in English where such phrases require an indefinite article (have a fall):

a. Kai den íthele se kamía períptosi na échei ${ }_{\text {BIASP }}$ ptósi me énan kainoúrio kinitíra

Gloss: And [he] did not want in any case to have fall with one new engine 'And he wanted under no circumstance to have a fall with a new engine'

b. Kalýtera min kánete kápoia kínisi, ísos kai na échei ${ }_{\text {BIASP }}$ apotychía

Gloss: Better not make any move maybe it have failure

'Better not make any move, it may have a failure'

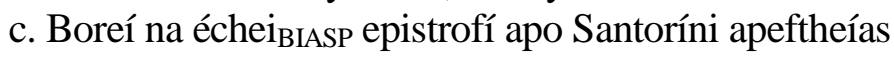

Gloss: [It] may have return from Santorini directly

'It may have a return from Santorini directly'

d. O Jacques proévi se diávima pros ton Morel, prokeiménou na échei ${ }_{\text {BIASP }}$ syzítisi me ton teleftaío

Gloss: The Jacques proceeded towards the Morel in order to have discussion with the latter

'Jacques took a step towards Morel, in order to have a discussion with the latter'

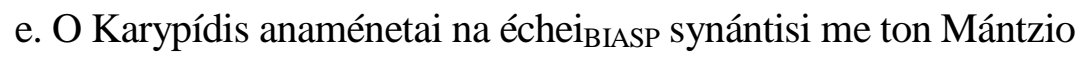

Gloss: The Karypídis [is] expected to have meeting with the Mántzio

'Karypidis is expected to have a meeting with Mantzio, 19

To the two groups in Tables 1 and 2, a third one must, however, be added nominals whose lexical meaning accommodates both perfectivity and imperfectivity: English opportunity, Bulgarian vazmozhnost, Greek efkairía, see (5)-(6) above. These could provisionally be called "biaspectual nouns". 20

Conversely, the have-forms in (9) in both Greek and English acquire imperfectivity after the lexical non-boundedness of an object-NP is mapped from the nominal onto the verb:
a. O Tzon eíche BIASP fantasía
a'. John had imagination

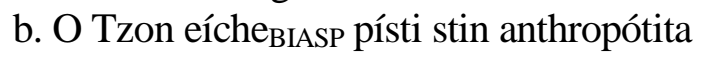
b'. John had belief in humanity

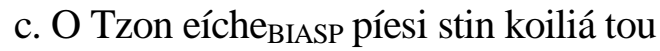
c'. John had pressure in his abdomen

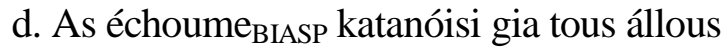
d'. Let us have understanding for others

\footnotetext{
${ }^{19}$ ome of the glosses reveal a specific feature of Greek, use of the article with proper names (people's), but whether this may be relevant or not (in some way) to the article-aspect interplay is beyond the goals of the study.

${ }^{20}$ See Kabakčiev (2000, pp. 218-222) for a detailed description of them.
} 
As already mentioned, non-bounded nominals as lexical entries do not require the use of an indefinite article in English or an indefinite numeral in Greek. Conversely, bounded nominals as lexical entries do require, in most cases, the use of the indefinite article in English (see Table 1). The boundedness of the relevant nominal (a fall, a refund, a talk, a party) resides in the lexical meaning but the indefinite article is still needed to explicate temporal boundedness (Kabakčiev 2000 , p. $211 \mathrm{ff}) .{ }^{21}$ Of course, a temporally bounded or non-bounded nominal in all the three languages can combine not only with have but with other verbs too: receive a refund instead of have a refund, feel pressure instead of have pressure, etc. But other verbs besides have (light or not) are not discussed here because in the Greek preterit they are marked for aspect and we are interested in biaspectuality only.

Analyzing (8), one might adopt the idea that it is solely the lexical temporal boundedness in the nominal that triggers perfectivity in the relevant aspectually unmarked have-form. This is not the case, for the following reasons. First, subjects such as personal pronouns or proper names are temporally bounded by default. They contain a covert definite article (see footnote 5) and temporal boundedness is mapped from them onto the (referent of the) have-verb. Second, let us construct some English sentences with bare-NP subjects and objects and analyze their Greek correspondences. English (10a) equals Greek (10a'), English (10b) equals Greek $\left(10 b^{\prime}\right)$ :

(10) a. In this study patients had an operation that restricted food intake

a'. Se aftí ti meléti, astheneís eíchan mia epémvasi pou periórize tin próslipsi trofís

b. Customers had an immediate refund for defective devices

b'. Pelátes eíchan ámesi epistrofí chrimáton gia elattomatikés syskevés

Here imperfectivity is explicated in the have-phrases in English and Greek and the Greek sentences are perfect examples of the functionality of Verkuyl's imperfective schema in Greek, otherwise a VA language. Note that when used independently or with a bounded subject as in (8), the have-phrases are perfective - temporal boundedness is explicated by the nominal and mapped onto the referent of the aspectually unmarked have-form. What happens in (10) is that imperfectivity in the have-phrases is explicated through Verkuyl's imperfective schema in the following way. The temporal non-boundedness of the (referents of the) relevant bare-NPs (patients, food intake, customers, defective devices, astheneís 'patients', epémvasi 'surgery') is mapped onto the (referents of the) verbs in the havephrases. The boundedness of the relevant NPs (an operation, a refund, epémvasi 'operation', epistrofi 'return') is thus canceled, and an indefinitely iterativized entity is produced, despite the presence in English of an indefinite article (an indefinite quantifier in Greek - mia epémvasi ‘an operation').

\footnotetext{
${ }^{21}$ Due to their structural significance, the English collocations of the have a fall/swim type are now covered in the World Lexicon of Grammaticalization (Kouteva et al. 2019, p. 343), where the explanation of their perfectivity is based on Kabakčiev's (2000, p. 212) concept of NP-V mapping.
} 
Let us now have Greek sentences with a prototypically biaspectual verb and not two but three situation-participant NPs, each of which can change the aspect of the initial perfective sentence, rendering it imperfective. Such sentences are rare, difficult to encounter or construct, hence valuable. ${ }^{22}$ But as Greek biaspectual verbs in the preterit receive aspectual marking, other conditions are needed for a biaspectual verb to be aspectually ambivalent. Meeting this requirement are future tense forms (among others). The aspectual values in (11), constructed sentences, are obtained through Verkuyl's schemata, according to the general CA mechanism:

(11) a. O valé tha parkárei ${ }_{\text {BIASP }}$ to aftokínitó mas ston kontinó chóro státhmefsis 'The valet will park our car in the parking lot nearby'

b. O valé tha parkárei ${ }_{\text {BIASP }}$ aftokínita ${ }_{\text {LEAK }}$ ston kontinó chóro státhmefsis

'The valet will park cars in the parking lot nearby'

c. O valé tha parkárei BIASP to aftokínitó mas se kontinoús chórous státhmefsis ${ }_{\text {LEAK }}$

'The valet will park our car in nearby parking lots'

d. Valédes LEAK $_{\text {tha }}$ parkároun BIASP $_{\text {to }}$ aftokínitó mas ston kontinó chóro státhmefsis

'Valets will park our car in the nearby parking lot'

If we add here the Bulgarian correspondences of Greek (11a-d) with the biaspectual verb parkiram 'park', it will be seen immediately that formally and semantically they are precisely identical, so we need not waste space for this. More importantly, the generalization that befits this cross-language and obviously universal picture obtained is: albeit peripherally, Greek and Bulgarian, VA languages, also feature CA. This generalization corroborates a statement put forward long ago (Kabakčiev 1984, 2000) and reiterated recently: "Verkuyl's theory [of CA] is a gigantic breakthrough in linguistics and its explanatory power is enormous" (Kabakčiev 2019, p. 213).

In a recent study of non-past $n a$-clauses in Greek, Fiotaki and Lekakou (2018) argue that while most verbs (including na thélo 'to want') allow the effectuation of perfectivity in the na-clause, there are some (e.g., vlepo 'see', akuo 'hear', arxizo 'start', stamato 'stop') that do not. The authors emphasize that this problem field, aspect in $n a$-clauses, is rather unexplored. Let us extend our observations to it and add a CA analysis:

(12) a. Thélo na parkáro BIASP to aftokínito

a'. I want to park the car

b. Thélo na parkáro ${ }_{B I A S P}$ aftokínita

b'. I want to park cars

c. Paidiá théloun na parkároun $n_{\text {BIASP }}$ to aftokínito

c'. Children want to park the car

\footnotetext{
${ }^{22}$ As shown in Kabakčiev (forthcoming), these sentences demonstrate how each NP referent triggers imperfectivization and how its temporal status changes along with the other two NPs.
} 
The compositional buildup works superbly in (12) - as previously in (11). Suppose there is a car near the garage that must be parked. Someone around can say (12a) in Greek or (12a') in English. The situation, in both languages, is perfective. But if the same person is an applicant for a valet job, he can say (12b) in Greek or (12b') in English. This situation is imperfective, indefinitely iterative, due to the non-boundedness of the referent of the object-NP. Note that English park the car and Greek parkároun to aftokínito are perfective phrases in isolation. But if near the garage there is a car that must be parked every evening and if there are children around who like to park cars, the garage attendant can now say (12c) in Greek or (12c') in English. The situation referred to is now imperfective, indefinitely iterative, and this is solely due to the non-boundedness of the (referent of the) subject-NP. This, again, corroborates Verkuyl's fundamental tenet that CA is unquestionably a sentence-level mechanism and that the impact of subject-NPs on aspect must never be overlooked. The Bulgarian equivalents of (12) are again fully identical formally and semantically, so the conclusions are valid for them too.

If an aspectually regular verb is to replace the biaspectual parkáro, it will be perfective in (13a)-(13a'), stathméfso, and imperfective in (13b)-(13c), stathmévoun (similar substitution is possible in Bulgarian). The grammatically encoded aspect matches the perfective schema in (13a)-(13a') with the boundedness of the subjectand object-NP, and the imperfective one in (13b)-(13c) with the non-boundedness of the object- or subject-NP:

(13) a. Thélo na stathméfsopfv to aftokínito

a'. I want to park the car

b. Thélo na stathmévo IMPFV aftokínita

b'. I want to park cars

c. Paidiá théloun na stathmévoun ${ }_{I M P F V}$ aftokínita

c'. Children want to park cars

After Vendler's (1957) insight that an object-NP changes the aspectual reading of a verb through the object-NP quantified/non-quantified alteration, it was Verkuyl's (1972) epochal discovery of CA that ultimately established that aspect cannot be properly understood without recognizing the impact of all sentence components, including the subject, as in the examples above. The grandeur of Verkuyl's discovery now becomes even more manifest, after the realization that $\mathrm{CA}$ also exists in VA languages like Greek and Bulgarian.

\section{On the Interdependence between Article, Aspect and the Aorist-Imperfect Distinction in a Cross-Language Perspective: Synchronic and Diachronic}

If the thesis about the article (definite and indefinite) as a marker of temporal boundedness on nouns is valid, it ought to be valid not only for Bulgarian as a borderline/hybrid language - with VA, an aorist-imperfect distinction and a definite article, but also for Greek, a language with precisely the same features. Kabakčiev failed to mention Greek as a borderline language in his initial 
publications, but has done it recently (Kabakčiev 2019, p. 218). Below we will analyze the relevant data to check if Greek behaves in the same way as Bulgarian. And if it does, it would have to be classified in future descriptions as belonging to the same structural cross-language paradigm and treated as a borderline/hybrid language: between the Germanic languages, on the one hand, using articles for explicating aspect (althe for perfectivity, zero article for imperfectivity) and featuring no VA of the Slavic/Greek type, and the Slavic languages, on the other hand, employing VA (including perfective verbs) and having no articles (save Bulgarian). But let us first place the article-aspect interplay in Greek and Bulgarian found so far into a larger cross-language perspective, as well as diachronically.

The idea of an article-imperfect interdependence in Bulgarian, launched in Kabakčiev (1984), was later complemented with a similar explanation of the English progressive (Kabakčiev 2000, pp. 163-180). The progressive is described, for the first time in linguistics, as "an expedient for eliminating the temporal boundedness of referents of subject- and object-NPs in sentences belonging to a particular (previously defined) major semantico-syntactic pattern" (Kabakčiev 2000, p. 180). Thus the raison d'être of the English past progressive partly coincides with that of the Bulgarian/Greek imperfect. This is logical, as the Bulgarian/Greek imperfect and the English past progressive, though not precisely identical grammemes, have a common value, viz., progressivity (Vendlerian activity), a subtype of imperfectivity. The difference is that while Bulgarian/Greek imperfects encode situations that are imperfective and are Vendlerian states or activities, the English past progressive also encodes situations that are imperfective but are only activities.

If the article and the aorist-imperfect distinction in languages from separate branches of the Indo-European genealogical tree such as Greek and Bulgarian are found to be structurally interrelated, it is worth exploring data from other languages, structurally different. Three recent publications, Bulatović (2019, 2020), Abraham (2020, p. 5) endorse Verkuyl-Kabakčiev's conception of Germanic aspect as mainly compositional and involving an interplay between verbal and nominal elements, including an article-aspect interplay - vis-à-vis Slavic aspect, predominantly verbal. In a truly revolutionary paper, Bulatović (2020) argues that $\mathrm{CA}$ and the article-aspect interplay as part of it are phenomena that are not simply and ordinarily valid, they are so hugely important that they must be taught to all learners of English (not only Slavic) and included in all English grammars to become part of the fundamental knowledge of native speakers. We fully endorse Bulatović's suggestions and we find that, apart from English and similar CA languages, they must also be applied to hybrid languages like Bulgarian and Greek - that manifest primarily VA but peripherally CA too.

But cross-language systematicity does not end here. In the year of publication of Kabakčiev's (2000) monograph on aspect revealing an article-aspect interplay in English and classifying Bulgarian as a hybrid language with CA and a definite article, another monograph appeared, Leiss' (2000), containing similar diachronic descriptions of three Proto-Germanic languages with a dying VA system and an emerging definite article - Old Icelandic, Gothic, Old High German. Leiss discovered an interplay in each of these languages between the disappearance of 
perfective verbs and the emergence of a definite article in nominals associated with formerly perfective verbs. In other words, two authors independently of one another launched the thesis that articles and aspect are interrelated, corroborating the idea of an all-embracing article-aspect interplay synchronically and diachronically: across languages different in their grammatical structures and across millennia. The two approaches complement each other, something mutually recognized by the authors (Abraham and Leiss 2012, p. 326; Kabakčiev 2018, 2019 , p. 216). Thus Leiss' generalizations about the fall of perfectivity and rise of the article in three Proto-Germanic languages structurally different from Greek and Bulgarian, and Bulatović's paper on CA and the article-aspect interplay in Modern English - structurally different from Old English, forcibly corroborate the idea of a momentous cross-language, synchronic-diachronic and truly universal articleaspect interdependence.

\section{Aorists and Imperfects Viewed as Vendlerian Situations}

Both Greek and Bulgarian feature an aorist-imperfect contrast, a mixed one, aspecto-temporal, in which the imperfect covers Vendler's imperfective situations states and activities, while accomplishments and achievements are covered by the Greek aorist and the Bulgarian perfective aorist. The aspectual value of the Bulgarian imperfective aorist thus remains outside Vendler's classification and for this reason a new Vendlerian situation was introduced in Kabakčiev (2000, pp. 279-307), termed "episode" - exemplified in (14a,b,c), morphologically realized by the imperfective aorist:

(14) a. Alexander tsaruva IMPFVAOR 12 godini

a'. Alexander reigned for 12 years

b. Spah ${ }_{\text {IMPFVAOR }}$ edin chas

b'. I slept for an hour

c. Deteto igra IMPFVAOR parka tazi sutrin

c'. The child played in the park this morning'

Actually the episode has a significantly larger representation both in Bulgarian and in cross-language terms. It covers all Slavic delimitative verbs, apart from Greek and Bulgarian it is also found in the Romance languages in certain uses of aorist forms, and in English it is fully systematically represented by for-time and similar adverbials, see $\left(14 a^{\prime}, b^{\prime}, c^{\prime}\right){ }^{23}$

The episode stands between Vendlerian imperfectives (states and activities) and true perfectives (accomplishments and achievements). Episodes are temporally bounded just like perfectives but lack the pragmatically interpretable feature "brought to a natural end" (achieved telos) and could therefore be called quasi-

\footnotetext{
${ }^{23}$ The episode appears to pose a problem to some linguists who regard it as unnecessary, a "pragmatic inference" (Ziegeler 2006, pp. 14-16). As already argued (Kabakčiev 2019, pp. 286$307)$, the episode is a situation widely found across languages in different grammatical and semantico-syntactic disguises.
} 
perfectives. Note that sentences such as (14) represent a major pattern. There are many thousands of such sentences in Bulgarian and English, explicating not true perfectivity but episodes. We need, therefore, to ask what the Greek correspondences of Bulgarian/English sentences like (14), representing an episode, would be. An answer, given by Vlachos' (2015, p. 13), is found in his example (15a) with a for-time adverbial, as well as in some sentences that we constructed, with temporal adverbials explicating specific situational meanings: ${ }^{24}$
a. O Geórgios vasílepse ${ }_{\mathrm{AOR}}$ gia 60 chrónia
'George reigned for 60 years'
b. Koimíthika gia ${ }_{A O R}$ mia óra
'I slept for an hour'
c. Épaixa ${ }_{\mathrm{AOR}}$ ténis símera to proí
'I played tennis this morning'
d. Épaixa $a_{A O R}$ éna paichnídi ténis símera to proí
'I played a game of tennis this morning'
e. Épaixa $a_{\mathrm{AOR}}$ éna paichnídi ténis gia mia olókliri óra símera to proí
'I played a game of tennis for a whole hour this morning'

Here vasílepse 'reigned', koimithika 'slept' and épaixa 'played' are aorists formed from perfective lexemes (Dimitrova 2019a, p. 188) and manifesting different kinds of aspect coercion. In (15a) the state verb vasilépso 'reign', is coerced from its immanent imperfectivity (lexical) into an episode simultaneously by the aorist and the phrase gia 60 chrónia 'for sixty years'. In (15b, c) koimithika 'slept' and épaixa 'played' are initially activities coerced from their immanent (lexical) imperfectivity into episodes by the aorist and by the adverbials gia mia óra 'for an hour' and símera to proí 'this morning'. In (15d) there is no coercion, as the accomplishment épaixa éna paichnídi ténis 'played a game of tennis' explicates true perfectivity (achieved telos) just like épaixa 'played' does. In (15e) there is again coercion - of the accomplishment épaixa éna paichnídi ténis 'played a game of tennis' from perfectivity (boundedness and achieved telos) into an episode, effectuated by the adverbial gia mia olókliri óra 'for a whole hour'. All this shows that the aorist in Greek engulfs lexical aspect, even defacing it, and temporal adverbials play a crucial part, coercing aspectual verb forms into one or another situational meaning. In Bulgarian almost no such coercion is observed. Temporal adverbials simply match the aspectual/situational meanings of the verb forms. Cf. (14a) above, where the imperfective aorist tsaruva 'reigned' and 12 godini 'for 12 years' are a faultless match, just like the episode meaning of imperfective aorists coincides with the limited-duration adverbials in (14b, c).

However, aspect coercion, i.e., forcing the aspectual/situational value of a grammatical form into a different aspectual/situational value through mapping as in (15a, b, c), can sometimes be observed in Bulgarian. See (3a) above, cf. also (16) from Kabakčiev (2000, p. 52), but these cases are rare:

\footnotetext{
${ }^{24}$ An anonymous reviewer argues that adverbials such as this morning or yesterday are different from durational adverbials. See our position in this section below.
} 
(16) Vrataryat imashe IMPFVIMP otlichna proyava i uspya da spasi duzpata

'The goalkeeper had an excellent feat and managed to save the penalty'

In (16), the boundedness of proyava 'feat' is mapped onto the verb imashe 'had', grammatically marked as imperfective by the imperfect.

It is remarkable that aspect coercion in Greek is also observed with imperfect verb forms, opposite to the one in (15) from true perfectivity (aorist) into an episode. In (17a) coercion is effectuated by the for-time adverbial gia misí óra 'for half an hour' - from an activity (encoded by the imperfect) into an episode:
a. I Eléni akouge
b. Elena slusha IMPFVAOR muzika polovin chas
c. Eleni listened to music for half an hour

But the result of the coercion in (15) and (17a) is ultimately the same: an episode. Discussing this issue, Vlachos (2015, p. 19) emphasizes that in such cases the two aspectually different verb forms manifest "the same duration in the past". Note that in the Bulgarian sentence (17b), equivalent to Greek (17a), there is no aspect coercion. The adverbial polovin chas 'for half an hour' matches the episode meaning encoded by the imperfective aorist slusha 'listened'. In the equivalent English sentence (17c) the adverbial for half an hour maps its episode meaning onto the verb listened, which is aspectually unmarked and manifests compatibility with three situations: state/activity/episode. Hence, here too, there is no aspect coercion, only mapping.

Some issues concerning adverbials need further clarification. First, for-time phrases are often said to be "durational adverbials" because they typically complement imperfective SV/VO/SVO patterns. In our understanding, for-time phrases are not durational adverbials. They are adverbials of limited duration (temporal boundedness) with two opposite functions. In English they usually combine with compositionally derived imperfective expressions, turning them into episodes - (17c). But for-time phrases also complement perfective phrases - cf. read the book in $X$ read the book for 2 hours, where, conversely, a perfective expression is turned into an episode. The specific Greek phenomenon is similar, in the sense that for-time phrases turn both perfectives and imperfectives into episodes - through aspect coercion. Second, in the three languages analyzed here (Greek, Bulgarian, English) there are thousands of adverbials that, strictly speaking, are not for-time phrases: yesterday, this morning, last month, etc. But they tend to explicate episodes just like for-time adverbials, and they do imply (if not exactly signify) limited duration. English (18a) naturally translates into Bulgarian (18a') with an imperfective aorist (an imperfective imperfect sounds deviant), which means that sentences with such adverbials prototypically explicate episodes:

(18) a. Yesterday/this morning/last month I played tennis

a'. Vchera/tazi sutrin/minaliya mesets igrah $_{\text {IMPFVAOR }}\left(*\right.$ ?igraeh $\left._{\text {IMPFVIMP }}\right)$ tenis 
Third, as both aorists (15a, b, c) and imperfects (17a) in Greek are coerced into episodes by for-time adverbials and adverbials like yesterday, this clearly increases the prevalence of the phenomenon. But certainly all these issues are in need of future research.

\section{The Article-Imperfect Interdependence in Bulgarian}

This interdependence, described in Kabakčiev (1984), answers the question what would happen if Bulgarian had only one preterit verb form (like the other Slavic languages) in SVO patterns with bounded participants. Below are two Bulgarian sentences to exemplify the issue (from Kabakčiev 1984, p. 655) impossible to translate, hence only glossed:

a. Mehanikat popravya/popravyashe $\mathrm{IMPFV}_{\mathrm{IMOR} / \mathrm{IMP}}$ kolata

Mechanic-the repaired car-the

b. Vojnikat presicha/presichashe IMPFV*AOR/IMP $_{\text {ulitsata }}$

Soldier-the crossed street-the

These are not real sentences but constructs containing a hypothetical single imperfective verb form common for aorist/imperfect. They resemble the preterit in English - which allows the explication of any aspectual value: the preterit is "an empty bag" capable of accommodating various aspectological meanings arising in sentences/contexts (Kabakčiev 2017, p. 232). If the verbs in hypothetical Bulgarian sentences such as $(19 \mathrm{a}, \mathrm{b})$ are unmarked for aorist/imperfect - because they represent constructs common for the two grammemes, there will be a tendency for such SVO sentences with definite articles, containing temporally bounded participants, to signal perfectivity, i.e., temporal boundedness. The conclusion, made 37 years ago (Kabakčiev 1984) and unchallenged, is that the Bulgarian imperfect exists to eliminate the temporal boundedness that would be triggered in the relevant nominal(s) in such sentences in the absence of other compensatory devices. In case of a no imperfect grammeme in Bulgarian, the temporal boundedness of such NP referents would be transferred onto the verb referent, triggerng perfectivity in it; while in many cases the intention of the speaker would be to present it as imperfective.

As for the aorist, it can firmly be maintained that it remains necessary for the system. All languages must be able to encode situations in the past as perfective/ imperfective with additional subtypes such as state/activity, true perfectivity/ episode, etc. Note that the hypothetical constructs in (19) belong to an important semantico-syntactic pattern (SVO) widely found across languages. The subject is an entity executing an action directed at another entity and triggering a pragmatic result. The cross-language existence of the pattern and its appropriateness for analyzing aspect is a key concept in both Verkuyl's and Kabakčiev's models, and the sidestepping of its significance and prevalence has recently been criticized by Bulatović (2020, p. 391): "the strong focus on internal arguments has overshadowed the role of external arguments in the calculation of aspect". The significance of this 
pattern underlies the existence in Bulgarian of two pairs of aspect markers: perfectivity-imperfectivity in the lexical verb, on the one hand, and a slightly different perfectivity-imperfectivity contrast (an aorist-imperfect distinction) in the verb as a syntactic entity. Bulgarian features four morphologically distinguished aspectual entities in the past: perfective aorist (izchisti 'cleaned completely'); imperfective aorist (chisti 'cleaned for some time'); perfective imperfect (izchisteshe 'cleaned indefinitely iteratively - whenever X cleaned); imperfective imperfect (chisteshe 'cleaned habitually/was cleaning'). In Greek only two forms exist: kathárise 'cleaned' (aorist); katharizei 'was cleaning/cleaned habitually' (imperfect). This comparison raises the question: how would the four morphologically distinguished Bulgarian aspectual values be rendered in Greek? (see below).

\section{On the Article-Imperfect Interdependence in Greek}

If we compare the Bulgarian hypothetical constructs in (19) against similar Greek material to check similarity with Bulgarian, it becomes clear that these Bulgarian constructs are not possible in Greek - because Greek features no imperfective aorist. Greek has two preterite forms: aorist, covering the Vendlerian situations accomplishment and achievement, and imperfect, covering states and activities:

O michanikós episkevástike ${ }_{\mathrm{AOR}} / \mathrm{episkévaze}_{\mathrm{IMP}}$ to aftokínito

'The mechanic repaired entirely/was repairing (repaired habitually) the car'

The system for effectuating perfectivity/imperfectivity in Greek, as exemplified in (20), is also different from the English one, where the preterit (indefinite/simple past) is unmarked aspectually, allowing subject- and object-NPs to signal temporal boundedness through the article (or other quantifiers) and map it onto the verb to achieve perfectivity. Imperfectivity as a Vendlerian state is achieved in English through a de-quantified participant, activities through progressive forms. In Greek, imperfectivity is effectuated directly by the verb - by the imperfect, just like in the Bulgarian imperfective imperfect. How can the Bulgarian-Greek difference - four versus two aspectual/situational forms in the preterit, be explained? The rich Bulgarian aspecto-temporal system allows certain elements in it to be found mimicking the Greek system:

(21) a. Detsa byagaha ${ }_{\text {IMP }}$ v maratona

'Childran ran/were running in the marathon'

b. Detsata byagaha ${ }_{\mathrm{IMP}} \mathrm{v}$ maratona

'The childran ran in the marathon'

Byagaha 'ran' is an imperfective preterit form unmarked for aorist/imperfect, which can be disambiguated in CA terms. In (21a) it is imperfective by default due 
to the non-bounded subject; in (21b) an episode is explicated through the bounded subject. Semantically byagaha 'ran' equals the two Greek verb forms in (15b) and (17a) together, an aorist and an imperfect - nominally different but both effectuating episodes. Bulgarian byagaha ${ }_{\mathrm{IMP}}$ 'ran' can be called a biaspectual in the past: an imperfective verb common for aorist/imperfect. Note, however, that this ambivalent status is not maintained in the singular, where the imperfect comes into play and imperfectivity is realized:

(22) a. Deteto byaga ${ }_{\text {IMPFVAOR }}$ v maratona

'The child ran [for X time] in the marathon'

b. Deteto byagashe ${ }_{\text {IMPFVIMP V maratona }}$

'The child was running/ran habitually in the marathon'

This is not surprising, as the plural in (21) allows disambiguation in CA terms between a state/activity and an episode through the bounded-nonbounded contrast in detsa 'children' vs detsata 'the children', while the singular does not. In Greek the aorist étrexe 'ran' and the adverbial ston marathónio 'in the marathon' render the Greek sentence (23a) semantically equal to the Bulgarian sentence (22a). But note that while in Bulgarian (22a) byaga $a_{\mathrm{IMPFVAO}}$ 'ran' is an episode in itself, directly encoded by the imperfective aorist, Greek étrexe ${ }_{\mathrm{AOR}}$ 'ran' in (23a) is coerced into an episode from pure perfectivity by ston marathónio 'in the marathon'. If we want to say that the child did the whole of the marathon, we will say (23b). If imperfectivity must be signified, this is done in (23c) by the imperfect étreche 'was running/ran habitually':
a. To paidí étrexe ${ }_{\mathrm{AOR}}$ ston marathónio
'The child ran [for X time] in the marathon'
b. To paidí étrexe $\mathrm{AOR}_{\mathrm{A}}$ ton marathónio
'The child ran the marathon'
c. To paidí étreche $\mathrm{IMP}_{\mathrm{MP}}$ ston marathónio
'The child was running/ran habitually in the marathon'

These issues are clearly in need of further research. But we can now hypothesize that, due to the systematic opportunity in Greek, and actually a necessity, to coerce perfective and imperfective verb forms into episodes using for-time and similar adverbials, the imperfective verbs have lost some of their imperfective potential and are perceived as truly imperfective in the past only by default, when unaccompanied by for-time or similar adverbials. The presence of a definite article in Greek capable of bounding temporally situation-participant NPs is probably another contributing factor - as in English, where it underlies the raison d'être of the progressive (Kabakčiev 2000, pp. 163-180).

But what about the Greek/Bulgarian aorist? If the raison d'être of the imperfect is to eliminate temporal boundedness in NP referents in certain sentences and thus prevent the transfer of temporal boundedness onto the verb referent, it is logically clear that the remaining member of the opposition, the aorist, cannot have an imperfective value - as this value is already occupied. On 
the other hand, in Bulgarian it would be illogical for the aorist to feature only the perfective value of lexical verbs, because the aorist would then simply equal VA perfectivity and would thus practically not exist - and the imperfect would then have no partner. The solution to the problem, triggered by the collective human brain governing the development of language, appears to have been to build such a contrast in Bulgarian in which the aorist enters no foreign territory and has a specific meaning of its own. Recall again that the Bulgarian aorist features true perfectivity - perfective aorist, or quasi-perfectivity, imperfective aorist, the latter encoding an episode. In Greek, the episode meaning is generated by for-time and similar adverbials, which systematically force the episode semantics onto either aorist or imperfect verb forms.

\section{Conclusion}

The analysis confirmed our preliminary conjecture that Greek is fairly similar to Bulgarian in structural and functional terms. It is a borderline/hybrid language featuring VA in verbs as lexical entries and specifically perfectivity (unlike CA languages like English that lack perfective verbs), an aorist-imperfect contrast, a definite article only (no regular pattern of an indefinite article). Greek, just like Bulgarian, also displays CA, including the article-aspect interplay, in certain peripheral conditions, especially when the aspectual meaning of the verb is not firmly fixed and hence susceptible to other situational values. An inseparable part of our approach was the understanding that situation-participant NPs are temporal entities. The investigation on Greek data here proved it once again to be completely valid, as was to be expected. A fruitful analysis of CA regularities without viewing situation-participant NPs as temporal entities is deemed impossible.

It is not surprising that two languages belonging to the Balkansprachbund, Bulgarian and Greek, share a considerable number of features related to CA. What is surprising and also somewhat difficult to analyze, is that they manifest specificities in the way CA values are explicated in verbs that are either biaspectual or changeable/coercible into aspectual values different from the ones they nominally express. As this study is an early attempt at exploring CA-VA values in Modern Greek, these specificities ought to be explored and described in future contrastive investigations of Greek and Bulgarian using the CA theory - possibly along with other languages, whether closely related or not.

\section{Acknowledgments}

We thank the editors of AJP for their kind assistance and the anonymous reviewers for their numerous and very reasonable comments - which we considered in detail and gladly took into account. We thank Panayiota Andrea for her help in clarifying some subtleties of Greek sentences. Desislava is deeply grateful to her late Greek grandmother and her half-Greek mother for having inherited from them practical knowledge of Greek. Finally, we, the authors, are 
more than happy to be able to offer to the linguistic community our thoughts on the study of the most important language in the history of the Western world.

\section{References}

Abraham W (2020) Modality in syntax, semantics and pragmatics. Cambridge Studies in Linguistics, Series Number 165. Cambridge: CUP.

Abraham W, Leiss E (2012) The case differential: syntagmatic versus paradigmatic case Its status in synchrony and diachrony. Transactions of the Philological Society 110(3): 316-341.

Andreou M, Tsimpli I (2017) Aspectual distinctions in the narratives of bilingual children. IRAL 55(3): 305-324.

Aubrey M (2014) The Greek perfect and the categorization of tense and aspect: toward a descriptive apparatus for operators in role and reference grammar. Dissertation. Langley, Canada: Trinity Western University.

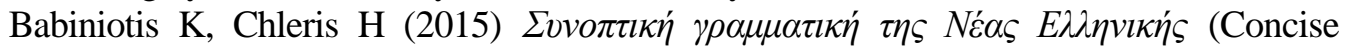
grammar of Modern Greek). Athens: Vima.

Bielecki RT, Trąba K (2018) Some general thoughts on tense and aspect in Modern Greek. Lingua Posnaniensis 60(2): 39-54.

Borer H (2005) The normal course of events. Oxford: OUP.

Borik O (2006) Aspect and reference time. Oxford: OUP.

Bulatović V (2013) Modern theories of aspect and Serbian EL2 learners. Belgrade English Language \& Literature Studies 5(1): 65-79.

Bulatović V (2018) Review of K.Kabakčiev. An English grammar: main stumbling blocks for Bulgarians learning English. Facta Universitatis Series: Linguistics \& Literature 16(1): 81-83.

Bulatović V (2019) Aspect semantics and ESL article use. IRAL. DOI: 10.1515/iral-20190016.

Bulatović V (2020) Thinking for speaking in the right aspect - On whether modern English grammars can do more. RESLA 33(2): 384-415.

Declerck R, Reed S, Cappelle B (2006) The grammar of the English verb phrase, Volume 1: the grammar of the English tense system, a comprehensive analysis. Berlin/New York: Mouton de Gruyter.

Dimitrova D (2019a) Kam vaprosa za markiraniya chlen na kategoriyata vid na glagola v novogratskiya ezik (On the issue of the marked member of the category verb aspect in Modern Greek). Savremenna Lingvistika 1: 49-56.

Dimitrova D (2019b) Gramatichni i funktsionalno-semantichni ekvivalenti na balgarskite glagolni vidove $\mathrm{v}$ novogratskiya ezik (Grammatical and functional-semantic equivalents of Bulgarian verb aspects in Modern Greek). In Verba iuvenium 1, 181195. Plovdiv: Paisii Hilendarski University of Plovdiv.

Dimitrova D (2019c) Yadreni i/ili periferiyni sredstva za izrazyavane na prezumptivna semantika v balgarskiya i novogratskiya ezik (Nuclear and/or peripheral means for expressing presumption in Bulgarian and Greek). Balgarski Ezik $i$ Iteratura 61(4): $399-406$.

Dimitrova D (2019d) Review [in Bulgarian] of K. Kabakčiev. An English grammar: main stumbling blocks for Bulgarians learning English. Sapostavitelno Ezikoznanie XLIV(4): 122-126. 
Dosi I (2017) Asymmetries in grammatical aspect in (non-)heritage Greek-English bilingual children: evidence from comprehension and production tasks. Studies in Greek Linguistics 37: 213-226.

Dosi I, Papadopoulou D, Tsimpli IM (2017). Issues in the acquisition of grammatical aspect in Greek-English bilingual children. In M Howard, P Leclercq (eds.), TenseAspect-Modality in a Second Language: Contemporary Perspectives, 75-103. Studies in Bilingualism 50.

Downing A, Locke P (2006) English grammar. A university course. London/New York: Routledge.

Dowty DR (1979) Word meaning and Montague grammar: the semantics of verbs and times in generative semantics and in Montague's PTQ. Dordrecht: Reidel.

Fenn P (2010) A Student's advanced grammar of English. Tübingen: Narr Francke.

Fiotaki A, Lekakou M (2018) The perfective non-past in Modern Greek: a corpus study. Scandinavian Journal of Byzantine and Modern Greek Studies 4(2018): 99-118.

Flouraki M (2006) Constraining aspectual composition. In S Müller (ed.), Proceedings of the $13^{\text {th }}$ International Conference on Head-Driven Phrase Structure Grammar, Varna. Stanford, CA: CSLI Publications, 140-157.

Georgakopoulos T, Härtl H, Sioupi A (2019) Goal realization: an empirically based comparison between English, German and Greek. Languages in Contrast 19(2): 280-309.

Holton D, Mackridge P, Philippaki-Warburton I (1997) Greek. A comprehensive grammar. New York: Routledge.

Horrocks G, Stavrou M (2007) Grammaticalized aspect and spatio-temporal culmination. Lingua 117(4): 605-644.

Huddleston R, Pullum GK (2002) The Cambridge grammar of the English language. Cambridge: CUP.

Kabakčiev K (1984) The article and the aorist-imperfect distinction in Bulgarian: an analysis based on cross-language 'aspect' parallelisms. Linguistics 22(5): 643-672.

Kabakčiev K (2000) Aspect in English: a "common-sense" view of the interplay between verbal and nominal referents. Dordrecht: Kluwer.

Kabakčiev K (2017) An English grammar: main stumbling blocks for Bulgarians learning English. Stuttgart: Mariana Kabakchiev Verlag.

Kabakčiev K (2018) Fleischhauer and Czardybon evade the burden of proof. Studies in Language 42(4): 967-969.

Kabakčiev K (2019) On the history of compositional aspect: vicissitudes, issues, prospects. Athens Journal of Philology 6(3): 201-224.

Kabakčiev K (forthcoming) Mapping temporal features between nominals and verbs in English and the article-aspect interplay diachronically. Belgrade English Language \& Literature Studies.

Kaltsa M (2012) The acquisition of telicity in the native language. Dissertation. Thessaloniki, Greece: Aristotle University of Thessaloniki.

Kitis E, Tsangalidis A (2005) Expressivity as an option if tense-aspect in language: the case of Modern Greek imperfective past. In S Marmaridou, K Nikiforidou, E Antonopoulou (eds.), Reviewing Linguistic Thought. Covering Trends for the $21^{\text {st }}$ Century, 142-162. Berlin/New York: Mouton de Gruyter.

Kouteva T, Heine B, Hong B, Long H, Narrog H, Rhee S (2019) World lexicon of grammaticalization. Second Edition. Cambridge: CUP.

Krifka M (1992) Thematic relations as links between nominal reference and temporal constitution. In IA Sag, A Szabolcsi (eds.), Lexical Matters, 29-53. Stanford, CA: CSLI Publication. 
Leiss E (2000) Artikel und Aspekt. Die grammatischen Muster von Definitheit (Article and aspect. The grammatical patterns of definiteness). Berlin: de Gruyter.

Marku H (2019) Kontseptsiyata za glagolniya vid v gratskoto ezikoznanie: razvoy i osnovni problemi (The concept of verbal aspect in Greek linguistics: development and major problem). Sapostavitelno Ezikoznanie XLIV(1): 45-57.

Sioupi A (2005) Morphological and telicity aspect with accomplishment VPs in Greek. In B Hollebrandse, A van Hout, C Vet (eds.), Corsslinguistic Views on Tense, Aspect and Modality, Cahier Chronos 13, 131-144. Amsterdam/New York: Rodopi.

Tarpomanova E (2013) Verb aspect in Greek and Bulgarian: derivation, meaning, functioning. In G Rata (ed.), Linguistic Studies of Human Language, 189-202. Athens: Athens Institute for Education and Research.

Trąba K (2019) The notion of completion in Modern Greek: an analysis of aspectively adversative sentences. Dissertation. Poznań.

Tsimpli IM, Papadopoulou D (2006) Aspect and argument realization: a study on antecedentless null objects in Greek. Lingua 116(10): 1595-1615.

Vendler Z (1957) Verbs and times. The Philosophical Review 66(2): 143-160.

Verkuyl H (1972) On the compositional nature of the aspects. Dordrecht: Reidel.

Verkuyl H (1993) A theory of aspectuality. The interaction between temporal and atemporal structure. Cambridge: CUP.

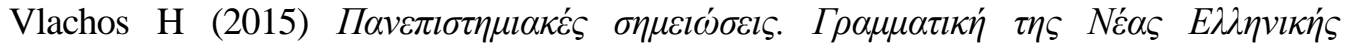
(University Notes. Grammar of Modern Greek). Ioannina.

Xydopoulos GI (1996) Tense, aspect, and adverbials in Modern Greek. Dissertation. London, UK: University College London.

Ziegeler D (2006) Interfaces with English aspect: diachronic and empirical studies. Studies in Language Companion Series 82. John Benjamins. 
